\title{
Review on Carbon Nanotube Varieties for Healthcare Application: Effect of Preparation Methods and Mechanism Insight
}

\author{
Jothi Ramalingam Rajabathar ${ }^{1, *}$, Govindasami Periyasami ${ }^{1, *(1)}$, Amer M. Alanazi ${ }^{2}$, \\ Mani Govindasamy ${ }^{3}$ and Prabhakarn Arunachalam ${ }^{1}$ (D) \\ 1 Chemistry Department, College of Science, King Saud University, Riyadh 11451, Saudi Arabia; \\ parunachalam@ksu.edu.sa \\ 2 Pharmaceutical Chemistry Department, College of Pharmacy, Kind Saud University, \\ Riyadh 11451, Saudi Arabia; amalanazi@ksu.edu.sa \\ 3 Department of Materials Science \& Engineering, National Taipei University of Technology, \\ Taipei 106, Taiwan; govind963@ntut.edu.tw \\ * Correspondence: jrajabathar@ksu.edu.sa (J.R.R.); pkandhan@ksu.edu.sa (G.P.)
}

Received: 22 November 2020; Accepted: 9 December 2020; Published: 15 December 2020

\begin{abstract}
Many potential uses of carbon nanotubes (CNT) in various sectors have created an urge to assess their diverse range of properties pertaining to various applications like catalysis, biosensor, and antimicrobial activity. Increasing studies on the biosensor and antibacterial activity of CNT have prompted tremendous interest in the utilization of the carbon-based nanostructured material as an alternative to currently existing antibiotics. However, the study of bactericidal aspects of this nanomaterial is relatively new and hence the deeper understanding of the various physicochemical characteristics and antimicrobial nature of CNT is extremely wanted. This review covers the effect of framework substitution and explains the understanding of membrane disintegration and oxidative stresses upon nanomaterials for antimicrobial activity. The present article has also reviewed effect of preparation nanoparticle deposition and framework modification on carbon nanotube structure. The recent research on graphene-modified nanomaterials for biosensor applications related to healthcare/clinical applications have also been discussed. Major physicochemical contributing factors such as size, functionalization, high surface area, and aggregation features of CNT assisting in the bacterial killing have nicely been outlined. Hence, the present review explains the supporting information related with Single and multi-walled carbon nanotube and summarized the advantages of functionalized carbon nanotube/graphene-based nanostructured carbon-based materials towards protection and reduction of bacterial/viral infections in the healthcare sector.
\end{abstract}

Keywords: carbon nanotube; E. coli; single wall carbon; catalyst; graphene oxide; carbon electrodes

\section{Introduction}

Carbon nanotubes (CNT) are one of the most promising and appreciated nanomaterials in the present time as well as in the past decades [1]. Excellent thermal conductivity, pore-size, and dimensions as well as electrical, mechanical, and magnetic properties of graphene and CNT varieties have made them one of the most applied materials in nanoscience and engineering technology [2]. Since its discovery in 1991, CNT have gained worldwide attention for its attractive and useful chemical, thermal, mechanical, and electrical properties and exceptional stabilities under normal environmental conditions [3]. They are made up of cylindrical tube of one or more layers of graphene sheets with a hexagonal structure. Currently, carbon nanotubes are found in two types: (1) single-walled CNT (SWCNT) that consist of a single layer of graphite sheet having diameter of $1 \mathrm{~nm}$ to $10 \mathrm{~nm}$ and length 
of several micrometers and (2) multi-walled CNT (MWCNT) are made up of more than one layer of graphene sheet that forms concentric circle towards the middle with variable diameters and length [4].

On the other hand, Fullerene (0D), Carbon nanotube (1D), and graphene oxide like two-dimensional (2D), Diamond-based carbon (3D) nanomaterial that have achieved remarkable attention for various applications such as catalysis, transistors-based DNA sensor, energy storage, bio-sensing, gene delivery, and drug delivery in recent years [5-28].

Usage of CNT in numerous fields has prompted a growing concern on the potential toxicity of this material towards human cells. The basic principle of bacterial action of carbon nanomaterials involves structural damage to the cell wall and membrane of microorganism. The carbon-based graphene sheets are capable of isolating cells from the microorganism and it eventually leads to cell death [12-16]. As toxicity of CNT towards human cell lines was obtained in past research reports, this has necessitated the interest to investigate the interactions of CNT towards microorganisms. The first evidence of antibacterial activity of CNT materials are reported in 2007, graphene like single layers of carbon nanotube (SWCNT) have claimed to exhibit strong antibacterial activity towards Escherichia coli [15-22]. Since then, various findings have indicated that physicochemical properties of CNT such as diameter, length, residual catalyst, electronic structure, functional groups on the surface, coatings of CNT, and dispersion factor affects the bacterial toxicity [16-20]. The general mechanistic action of CNT towards bacterial cells involves membrane disruption and oxidative stress [23]. Generation of reactive oxygen species (ROS) by the CNT upon exposure to bacterial cells causes destructive effects to components of cell mainly through lipid peroxidation methods [24]. Additionally, oxidative stress response genes such as oxyR and soxRS in E. coli were up-regulated after exposure to CNT and this clearly indicates the involvement of oxidative stress as a mechanism of action of CNT [16,25]. In this pandemic situation, recently some interesting articles reported for the detection and label free platform for virus analysis using Carbon nanotube array-based microfluidic device fabrication [26]. They constructed a microfluidic platform with differential filtration porosity for the rapid enrichment and identification of viruses by surface enhanced Raman spectroscopy. The captured viruses remain viable in chip-based microfluidic devices and are purified in a micro device followed by detail characterization by conventional biological methods [27].

Therefore, the present review is explained in details related with effect of framework additive addition on Carbon nanotube and their influences in the antimicrobial mechanisms. Figure 1 shows the various preparation methodology for carbon nanotube formation and highlighted applications related to present article such as biosensors and antimicrobial activity of CNT.

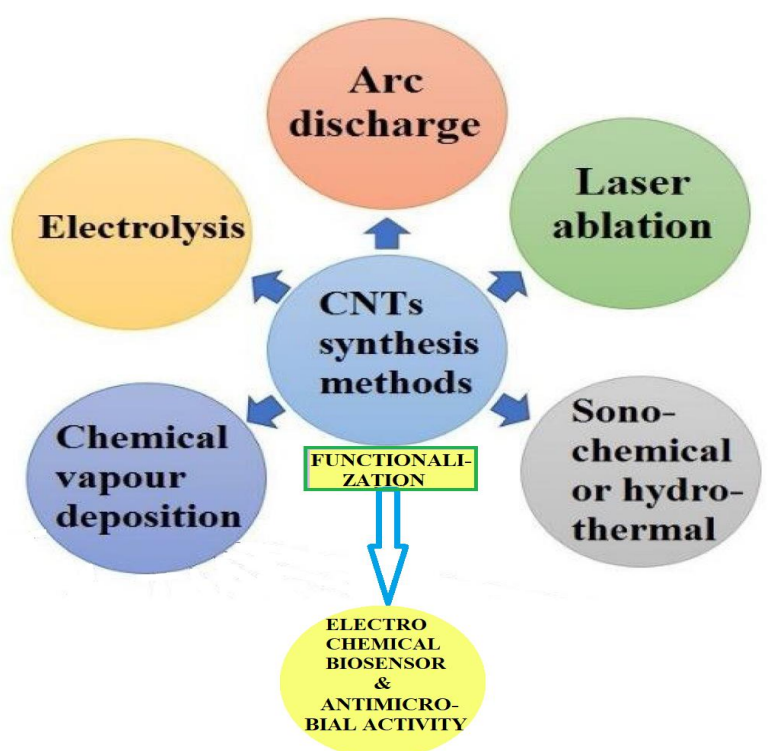

Figure 1. Carbon nanotube (CNT) preparation method and its potential application (our own original image). 


\section{Summary of the Review Article}

The following sections deal with the antimicrobial activity and mechanistic aspects of CNT (SWCNT and MWCNT) and functionalization of carbon network like in CNT and graphene nanomaterials for efficient Biosensor and Antimicrobial action. Table 1 highlights the role of materials that are used for suitable pathogens and its mechanism action such as cell damage or oxidative mechanism are explained in detail. The present review article is also focused to explain the role of particle size and morphology of different variety of carbon nanotube in Antibacterial activity for infection control. The electronic structure of CNT is discussed with respect to their framework modification. Graphene oxide modified nanocomposite electrode application of various CNT morphology has compared and exploited their outcome property.

\section{Results and Discussion}

\subsection{Effect of Preparation Method and Functionalization on CNT for Biosensor and Antibacterial Activity}

Carbon nanotube, SWCNT, and MWCNT materials can be prepared by many preparation methods such as chemical vapor deposition, laser ablation, flame synthesis (burning of carbon precursor in the presence of flame to collect the deposits), and nanoparticle assisted catalytic synthesis of MWCNT. The graphene oxide synthesis from graphite has been very popular in past decades to fabricate the reduced graphene oxide or graphene layer for electrochemical sensor and catalytic applications. Effects of synthesis strategy and addition of extra additive for modified CNT materials play an important role for achieving the higher efficiency to get the final product. Recently, our group reported Molybdenum disulfide Nano sheets dispersed as an additive component in MWCNT and it is applied on bio-sensing application towards determination of chloramphenicol (CAP) in milk, honey, and condensed milk samples [27]. Figure 2 shows the schematic image of functionalization of MWCNT in acidic medium followed by in situ formation of $\mathrm{MoS}_{2}$ on the surface of carbon nanotube matrix. The $\mathrm{MoS}_{2}$ functionalized MWCNT shows the higher selectivity for the determination of CAP $(0.8-1.3 \mu \mathrm{M})$ compared to gold nanoparticle functionalized graphene oxide (1.5 to $2.5 \mu \mathrm{M})$. The higher detection limit $(0.015 \mu \mathrm{M})$ was achieved by nanoparticle functionalization on MWCNT due to negatively charged acidic group and blended with incoming nanoparticle and forms the interconnected three dimensional (3D) network of multi walled carbon nanotube as shown in Figure 2.

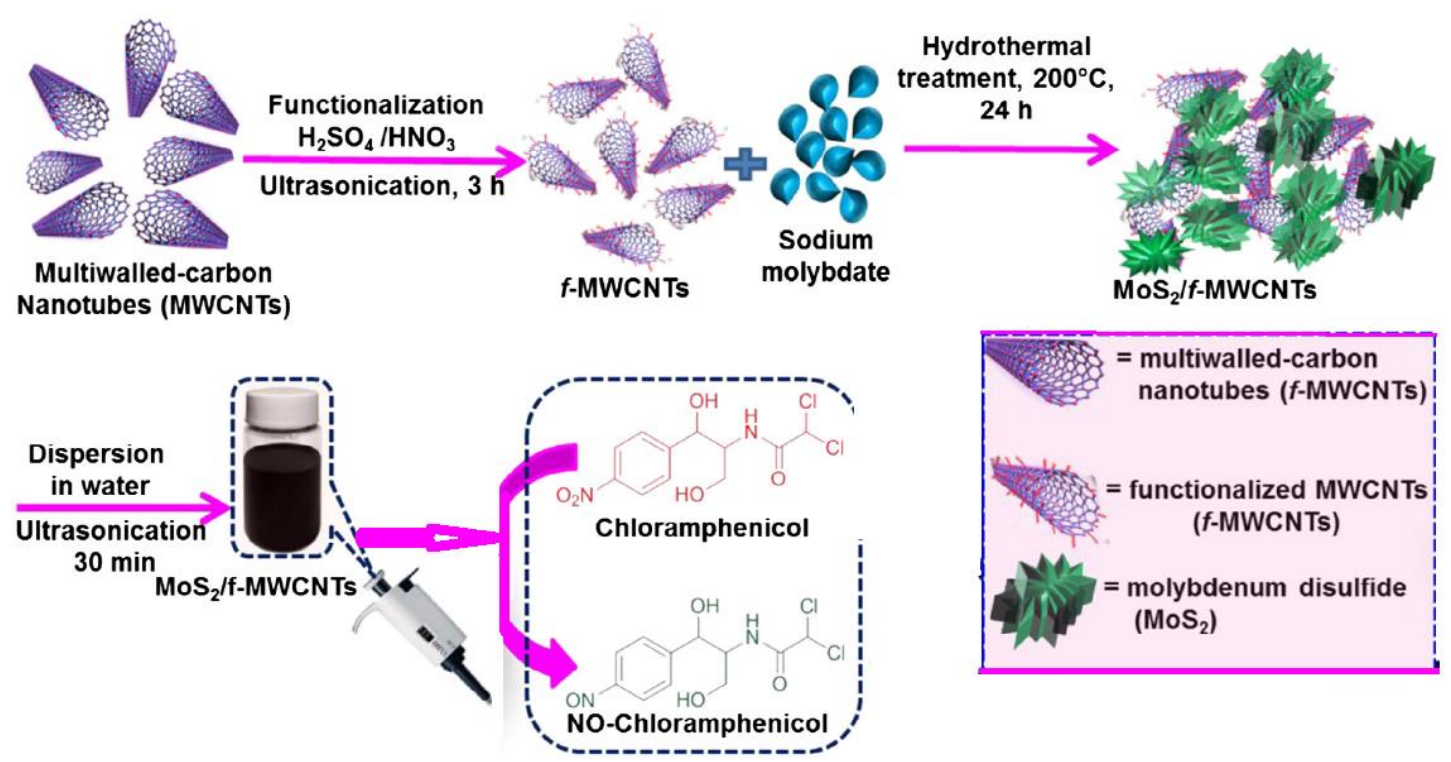

Figure 2. Effect of preparation and functionalization of $\mathrm{MoS}_{2}$ with MWCNT (reproduced and modified from our own publication report with copy right permission from Elesvier). 
In another related work on MWCNT, we reported the determination of dopamine using graphene oxide and carbon nanotube hybrid decorated with nanoparticle of $\mathrm{MoS}_{2}$. Dopamine (DA) is a kind of neurotransmitter in mammalian central nervous systems which facilities communication between brain and neurons. To maintain the healthy human system, dopamine plays an important role. To determine DA, we fabricated first hybrid composite formation using graphene oxide from low cost graphite by hammers method. In the second step, the graphene oxide treated with commercial carbon nanotube to form hybrid nanostructure followed by in situ addition of sodium molybdate in hydrothermal process to form the nanoparticle of $\mathrm{MoS}_{2}$ followed by insert into the composite structure. Hydrothermal process is facilitating the graphene oxide Nano sheets binding with as formed nanoparticles of $\mathrm{MoS}_{2}$ with flower morphology and deposited strongly on nanotubes of carbon network, which is shown schematically in Figure 3. The as prepared modified electrode show effective results at nano-Molar (nM) concentration of DA detection. Voltammetry technique shows the sensing limit of $100 \mathrm{nM}-100 \mu \mathrm{M}$ with low detection limit of $50 \mathrm{nM}$ [28]. Hence, to achieve the above sensitivity to biological molecules purely depends on preparation strategy adopted in the formation of carbon nanotube and graphene-based modified composite materials fabrication.

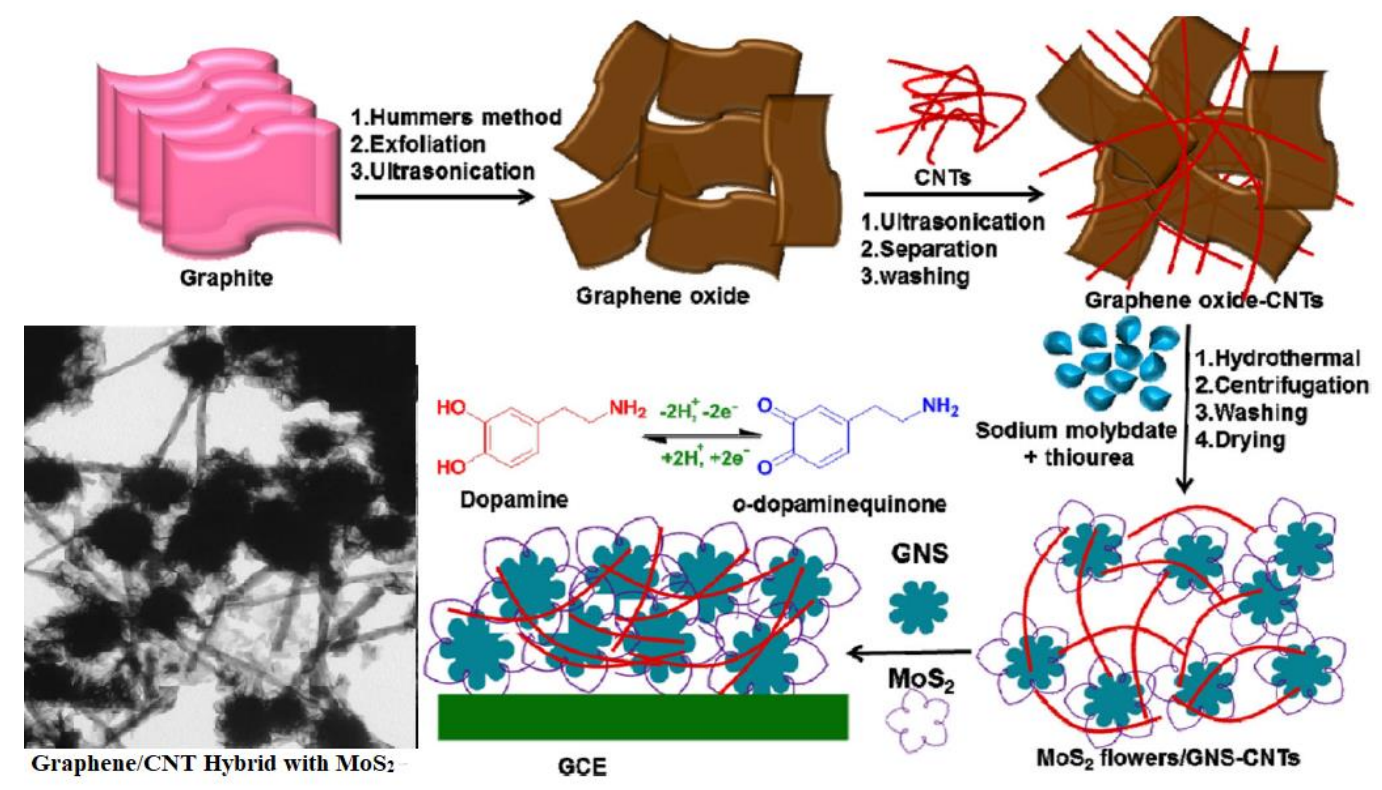

Figure 3. Functionalization strategy for Graphene oxide/CNT by $\mathrm{MoS}_{2}$ nanoparticle formation (Reproduced with permission, modified picture of our own published work).

\subsection{Antimicrobial Activity and Mechanistic Insights of CNT (SWCMT and MWCNT)}

In addition to the various medical, chemical, physical, and engineering contributions of carbon nanomaterials in the real-world applications, antibacterial and future antiviral potential of CNT has collected enough credits worldwide to be well acclaimed and researched for the utilization of this carbon nanomaterial for the application in the field of Nano-biotechnology [25-28]. However, the mechanistic action of CNT has not been elucidated clearly and conflicting results achieved through inconsistent experimental setup is undoubtedly the main culprit of these circumstances [29-38]. This review will focus exclusively on the antimicrobial potentials of CNT, in addition to the mechanistic aspects that are involved during the interactions between the nanomaterial and the microorganism, especially among the bacterial cells.

Although substantial effort has been devoted to explore the beneficial prospects of CNT in the revolutionary field of biomedical sciences, the applications of these nanomaterials are considered for use in combating the ever-increasing microbial infections especially in the clinical setting and hospital atmosphere due to many years of negligent usage of antimicrobial agents [29-38]. Table 1 shows the 
variety of carbon nanomaterials and its contributing factor toward mechanism action in antimicrobial property. Carbon nanotubes tremendous antibacterial potency have triggered immense interest to investigate the potentials of CNT as coating agents or protective film on medical instrumentations, especially in the hospital settings to prevent the spread of nosocomial infections [39-44]. Application of CNT in wound dressings have been exploited for use in any injury with the risk of bacterial infection. However, this dressing is similar to conventional bandages, but the antiseptic solution embedded along with the SWCNT would undergo a slow-release as it is in the woven material of the bandage $[45,46]$.

Table 1. Brief description of antibacterial activity and its mechanism insights of CNT varieties.

\begin{tabular}{|c|c|c|c|c|}
\hline $\begin{array}{c}\text { Carbon } \\
\text { Nanomaterials }\end{array}$ & Bacteria & Contributing Factor & $\begin{array}{c}\text { Mechanism } \\
\text { of Action }\end{array}$ & References \\
\hline $\begin{array}{l}\text { Fullerenes } \\
\text { MWCNT }\end{array}$ & $\begin{array}{l}\text { E. coli } \\
\text { E. coli }\end{array}$ & $\begin{array}{l}\text { Silver nanoparticle } \\
\text { modification on C60 } \\
\text { Uncapped, short, } \\
\text { debundled and highly } \\
\text { dispersed in solution }\end{array}$ & $\begin{array}{l}\text { Synergistically target } \\
\text { bacterial cells that } \\
\text { increase ROS } \\
\text { Membrane damage }\end{array}$ & $\begin{array}{l}{[31]} \\
{[17]}\end{array}$ \\
\hline SWCNT & E. coli $\mathrm{K} 12$ & $\begin{array}{l}\text { Direct contact between } \\
\text { bacterial cell and SWCNT } \\
\text { in solution }\end{array}$ & Membrane damage & [15] \\
\hline $\begin{array}{l}\text { SWCNT } \\
\text { MWCNT }\end{array}$ & E. coli & $\begin{array}{l}\text { Higher surface area } \\
\text { of SWCNT }\end{array}$ & Membrane damage & [16] \\
\hline SWCNT & Soil microorganisms & $\begin{array}{l}\text { Raw SWCNT enhances } \\
\text { metal toxicity in the soil }\end{array}$ & $\begin{array}{l}\text { Suppressed } \\
\text { metabolic activity }\end{array}$ & [47] \\
\hline SWCNT & E. coli $\mathrm{K} 12$ & $\begin{array}{l}\text { Aggregation } \\
\text { characteristics }\end{array}$ & Bacterial inactivation & [19] \\
\hline SWCNT & E. coli $\mathrm{K} 12$ & Increasing metallic fraction & Oxidative stress & [48] \\
\hline CNT & $\begin{array}{l}\text { E. coli, Shigella sonnei, } \\
\text { Klebsiella pneumoniae, } \\
\text { P. aeruginosa, }\end{array}$ & Presence of light & Oxidative stress & [24] \\
\hline $\begin{array}{l}\text { SWCNT } \\
\text { MWCNT }\end{array}$ & $\begin{array}{l}\text { Lactobacillus } \\
\text { acidophilus, } \\
\text { Bifidobacterium } \\
\text { adolescentis, E. coli, } \\
\text { Enterococcus faecalis, } \\
\text { S. aureus }\end{array}$ & $\begin{array}{l}\text { Wrapping mechanism } \\
\text { influenced by length and } \\
\text { piercing mechanism } \\
\text { dependent on diameter }\end{array}$ & $\begin{array}{l}\text { Membrane damage, } \\
\text { release of DNA and } \\
\text { RNA, potential } \\
\text { reduction of } \\
\text { bacterial membrane }\end{array}$ & [49] \\
\hline $\begin{array}{l}\text { Graphene } \\
\text { oxide }\end{array}$ & E coli & aggregation of GO & $\begin{array}{l}\text { extraction of } \\
\text { phospholipids }\end{array}$ & [50] \\
\hline
\end{tabular}

\subsection{Funtionalization of Carbon Nanotube for Antimicrobial Action to Control Infections}

Carbon nanotube-based 1D and 2D nanomaterial are being regarded as the best invention of nanotechnology as the utilization of this nanomaterial could be playing as special category components in the field of chemical, bio-chemical engineering, medical and electrical sensor industry [40-45]. Although the discovery of CNT was made in 1991, the antimicrobial potential of this nanomaterial was not made until 2007 [15,50-65]. Recent findings in mechanistic pathway for damage of human cell for antimicrobial potential of CNT are greatly influenced by the unique physicochemical properties of this nanomaterial such as size, length, diameter, surface functionality, dispersivity, and agglomeration factors [47-51].

Carbon nanotubes are usually extreme insolubility in aqueous and organic solvents was the main limitation for CNT utilization in diverse range of fields. Given that the diameter of SWCNT are in the range of $0.4-3 \mathrm{~nm}$ and in the range of 1.4-100 $\mathrm{nm}$ for MWCNT, while the length of these nanomaterials are often in the range of micro-meters to millimeters, moreover it is a known fact that CNT are usually not equivalent in diameter and length [60-62]. Modification of surface chemistry of 
this material with functional group that are strong oxidizing agents have tremendously improved its dispersivity in aqueous solution for improved utilization in biotechnology [66]. Figure 4 demonstrates the effect of CNT particle size and functionalization results in changing its properties and efficiency. Functionalization and purification steps significantly transform the physicochemical nature of CNT to progress with modifications in cytotoxicity against the bacterial model. Attachment of polar functional groups like hydroxyl and carboxylic groups on the sidewalls and open ends of the nanotube mainly increases the dispersivity of the nanomaterial and simultaneously increases the potential use of CNT to be employed in various other fields $[17,65-73]$.

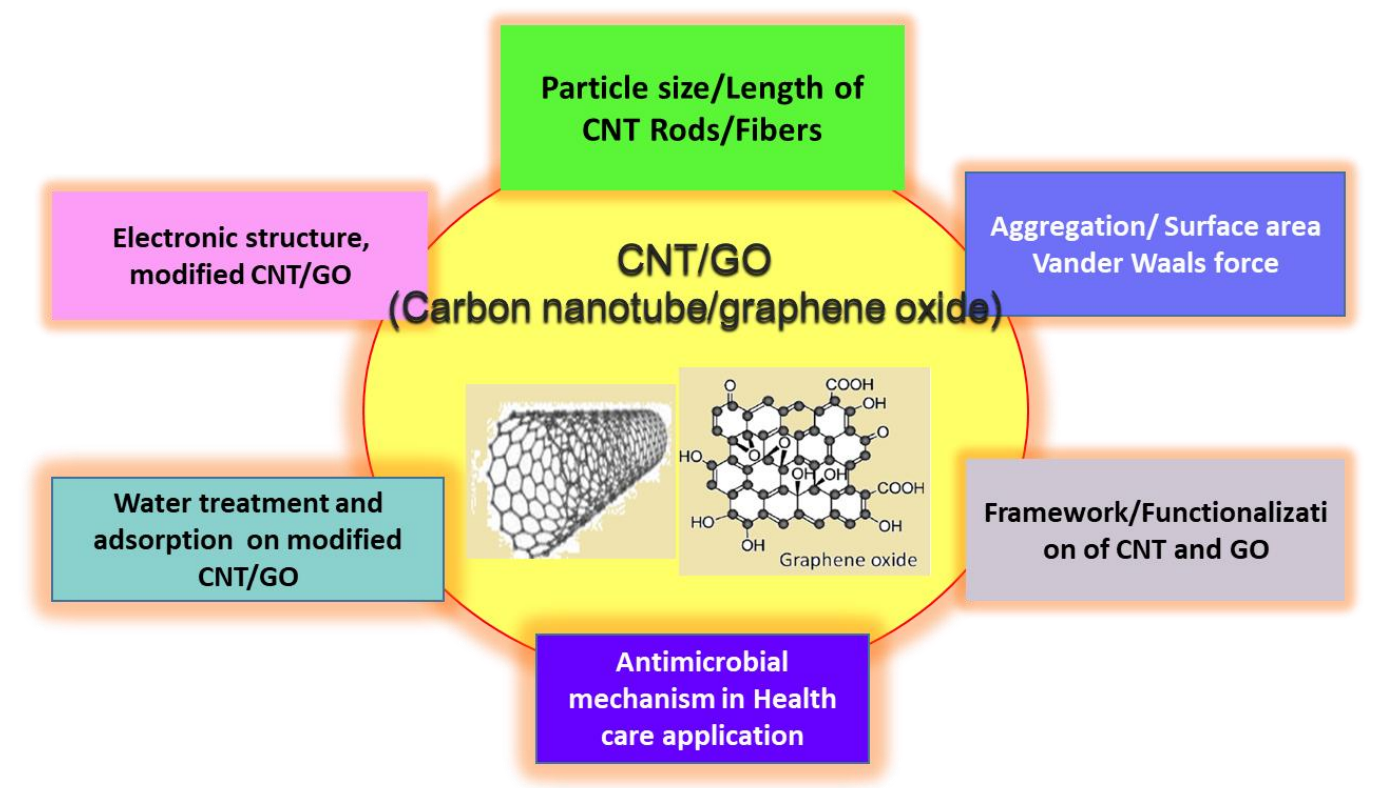

Figure 4. Effect of preparation strategy upon functionalization, physico chemical property, and its potential application in various field [60] (modified image reproduced with permission).

Commercial exploitation of CNT is heavily dependent on the physical, chemical, and structural characteristics of the carbon-based nanomaterial. Functionalization of carbon nanotube depends on many factors such as solvent usage to dissolve the precursor, time of reaction, ageing process are all plying a key role in improve the electronic and structural properties of carbon nanotube [60]. These formations of defects caused by functionalization might play a role in determining the toxic effects against bacteria. Contradictory results in the literature regarding the toxicity of CNT have often fueled the enthusiasm to conduct toxicity assays for the nanotubes due to the large difference of outcomes observed in CNT-mediated toxicity [21,74,75]. For instance, inactivation rate of bacteria models (B. subtilis, E. coli, and S. aureus) were demonstrated to increase with the addition of functional groups on the surface of CNT, which in turn, have increased the dispersivity of the nanotubes [72-74]. Besides that, another report has linked the toxicity effects of functionalized CNT, especially with the attachment of carboxyl group, to the presence of amorphous carbon species that are detected through Raman spectra. The various functional group addition, role of carbon nanotube length, size effect towards its potential application, and physico chemical property variations (Figure 4). The length of nanotubes is important during its interaction with cell membrane. The shorter SWCNT shows the higher activity for bactericidal performance than longer SWCNT [72-74]. In liquid medium, short lengths of CNT are more likely self-aggregate without involving a large number of microbial cells and its vice versa in the case of lengthier carbon nanotube. The diameter of tube also plays an important role in bacterial inactivation process. Smaller diameters can provide higher damage to cell membrane though the cell-surface interaction [74,75]. The existence of the additional carbon species was generated through acid treatment protocol were utilized to carboxylate the carbon nanotube surface. Therefore, carbon-based nano-products that are utilized in medical field should be developed 
based on highly purified condition in preparations and functionalization process to avoid the other carbon species interference or contaminates with single walled carbon nanotubes [70-75]. Aggregation and dispersivity characteristics of functionalized CNT should be considered, when envisaging the possibility of toxic effects of the nanotube towards the experimental bacterial model. An article researching these circumstances has demonstrated that aggregation characteristics of functionalized SWCNT have to be taken into consideration foremost for predicting the likelihood of the bactericidal effects of the CNT as the group found that compact and narrow distribution of aggregates poses a reduction in toxicity $[18,19]$. Hence, an elevation in the toxicity characteristics of the CNT is not exclusive to one factor and its length, diameter, and nature of functional group exist in the surface create the unique carbon-based nanomaterials for selective killing of bacterial pathogens.

\subsection{Role of CNT in Oxidative Stress Property in Cell Membrane}

Another possible mechanism experienced by CNT with bacterial cells is reactive oxidative stress. The initial study that was examined by the bacterial response involving CNT and oxidative stress mechanism reported that more than $50 \%$ of bacterial genes were up-regulated upon exposure to SWCNT. The interaction between SWCNT and membrane damage related to bacterial oxidative stress response system involving oxyR and soxRS [16]. Figure 5 clearly explains the production of singlet oxygen $\left({ }^{1} \mathrm{O}_{2}\right)$, hydroxyl radicals $\left({ }^{\bullet} \mathrm{OH}\right)$, and superoxide anions $\left(\mathrm{O}_{2}{ }^{\bullet-}\right)$ are generated in a step by step process and classified under reactive oxygen species (ROS) where ROS are mostly by-products of aerobic respiration conducted by the bacterial cells (Figure 5A). However, the bacterial cell experiences inadequacy in the elimination of additional ROS as exogenous production of ROS is being generated by the CNT in the aqueous media through photo induction $[24,56]$.

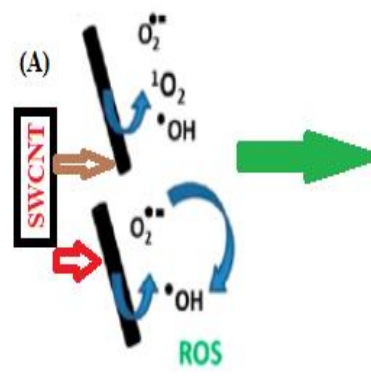

I. Generation of ROS

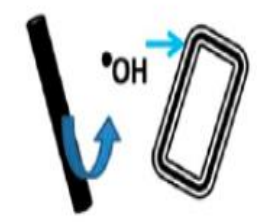

II- Oxidative stress on cell surface
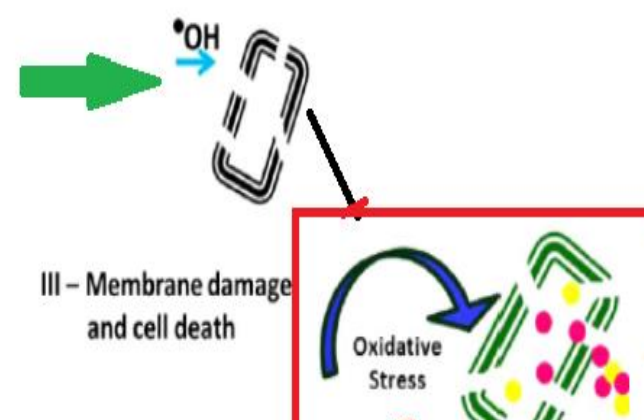

(B)

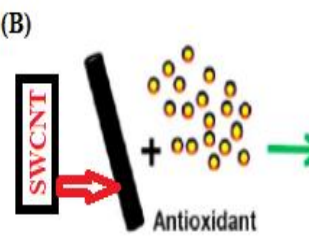

I-Antioxidant

II-Antioxidant

coated CNTs

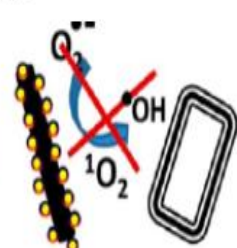

III - Reduction of

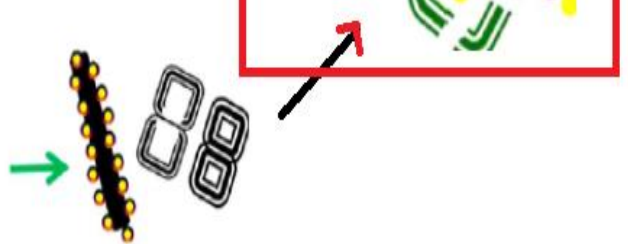

IV - Cell proliferation

Figure 5. Schematic representation of oxidative stress-mediated cell death and its amelioration by antioxidant treatment. (A) Oxidative stress (ROS)-mediated bacterial cell death. (B) Protection of bacterial cells against oxidative stress by an antioxidant [24] (modified image and Reproduced with permission and cited in the reference, from ACS chemical Society).

Figure 5A,B shows the cytotoxicity properties that may be exerted by ROS includes damaging effects to the lipids, nucleic acid, proteins, and carbohydrate-moieties and generation of ${ }^{\bullet} \mathrm{OH}$ is considered the most damaging species as it causes instantaneous reaction with the fatty acids, proteins, and sugar molecules and initiates a rapid stimulation of lipid peroxidation activity that 
causes membrane disintegration and subsequent leakage of cytosol content into the surrounding environment $[16,24,49]$. Lipid peroxidation reactions are mediated through a Fenton-like reaction that generates hydroxyl radicals, which in turn induces structural damages to the lipid bilayer of the bacterial membrane through unsaturated fatty acids peroxidation process [57].

Since ROS is a by-product of bacterial undergoing oxidative stress, therefore it is naturally assumed that existence of this reactive species is beneficial in moderate levels where generation of ROS stimulates the production of regulons to reduce the damaging effects of oxidative stress [58]. However, exposure of CNT to the bacterial cells induces the formation of ROS and additionally the CNT material itself generates ROS, therefore, an overwhelming presence of ROS creates lesions that causes cellular damage and an eventual cell death [59].

\subsection{Role of Particle Size and Morphology in Antimicrobial Action}

The unique microbicide strength of carbon nanotubes mainly lies on its nano-scale characteristics and although all materials in this scale of length are often referred to as nanoparticles, results in the greatest antimicrobial toxicity effects [60]. SWCNT with smaller diameter measurements in contrast to MWCNT has higher antibacterial potential as demonstrated for the first time in 2008. In this study, these two nanomaterials were subjected to exposure towards E. coli for $60 \mathrm{~min}$ and better antibacterial activity of SWCNT were associated to its small diameter that contributed towards penetration of the nanotube into bacterial cell walls which were highly effective due to the improved surface area and generation new active sites in the carbon nanotube surface could promotes effective interaction with bacterial cells [16]. Similarly, SWCNT have better toxicity effects towards E. coli, P. aeruginosa, B. subtilis, and S. aureus compared to MWCNT, aqueous phase C60 (fullerene) nanoparticles, and colloidal graphite. Although moderate amounts of toxicity were observed with MWCNT, graphene oxide, and colloidal graphite, SWCNT was clearly the best candidate for eradicate the bacterial contaminants especially in river water and wastewater effluent treatments [61]. The authors suggested that further antimicrobial studies must take into account the difference in membrane structure of Gram positive bacteria, especially B. subtilis as variations in the membrane potential would play a greater role in determining its susceptibility towards CNT. This was due to the longer incubation time imposed on the B. subtilis isolate to achieve similar toxicity effects as observed on other bacteria models [61]. Moreover, this specialty in the diameter size also facilitates partitioning and partial penetrations of the nanotubes into the outer membrane of bacterial cells and causes irreversible membrane damage [16].

Comparison between the SWCNT and MWCNT proves that a large difference in their respective lengths greatly influences the mode of interaction with the bacterial cells as shorter lengths of SWCNT have a higher amount of surface area for interaction with additional open end of the nanotubes. However, this is clearly not the case with MWCNT that are nearly $70 \mu \mathrm{m}$ and SWCNT which are merely $2 \mu \mathrm{m}$, thus improvement in contact with bacterial cells which promotes bacterial toxicity effects are clearly seen with SWCNT [16]. Although an enormous dissimilarity in length specification that is present between the SWCNT and MWCNT have elicited variations in bacterial toxicity, however, additional study was initiated to record deviations in bactericidal effects garnered through difference in length among the SWCNT [62-70].

Carbon nanotube materials have shown greater activity in the case of bacterial cells in the form of biofilms. In the past reports predict that the $80-90 \%$ of microbial cells were damaged in the case of SWCNT coating on polymer substrate towards E. coli and B. subtilis bacteria [68-70].

Three types of SWCNT length were investigated for their exposure towards a common food-borne pathogen, S. typhimurium, and ironically, the longest of the studied SWCNT models $(\sim 5 \mu \mathrm{m})$ recorded the most effective antimicrobial activity in comparison to SWCNT which were $<1 \mu \mathrm{m}$ and $1-5 \mu \mathrm{m}$ correspondingly as depicted through growth curves in Figure $6 \mathrm{~A}-\mathrm{C}$ where growth curve $\mathrm{C}$ shows the most significantly affecting parameter. Figure $6 \mathrm{~A}-\mathrm{C}$ indicates the longer time required for the bacterial cells to reach optical density at $600 \mathrm{~nm}(\mathrm{OD} 600 \mathrm{~nm}$ ) compared to other carbon nanotube lengths. Although it was an expectation that shorter SWCNT would possibly have the best antimicrobial 
potential through existence of more open ends of the nanotubes, but this was clearly not the only factor that determines the antibacterial potential of the SWCNT. The author implied that aggregation factor also regulates toxicity factor of SWCNT where the longer SWCNT $(\sim 5 \mu \mathrm{m})$ formed aggregates involving a larger number of bacterial cells compared to the $<1 \mu \mathrm{m}$ SWCNT which had a tendency to form self-aggregates without the involvement of a significant number of bacteria cells. Formation of aggregates have prompted better interaction among the SWCNT and the cells, that have ultimately affected the mortality of the bacteria [62].
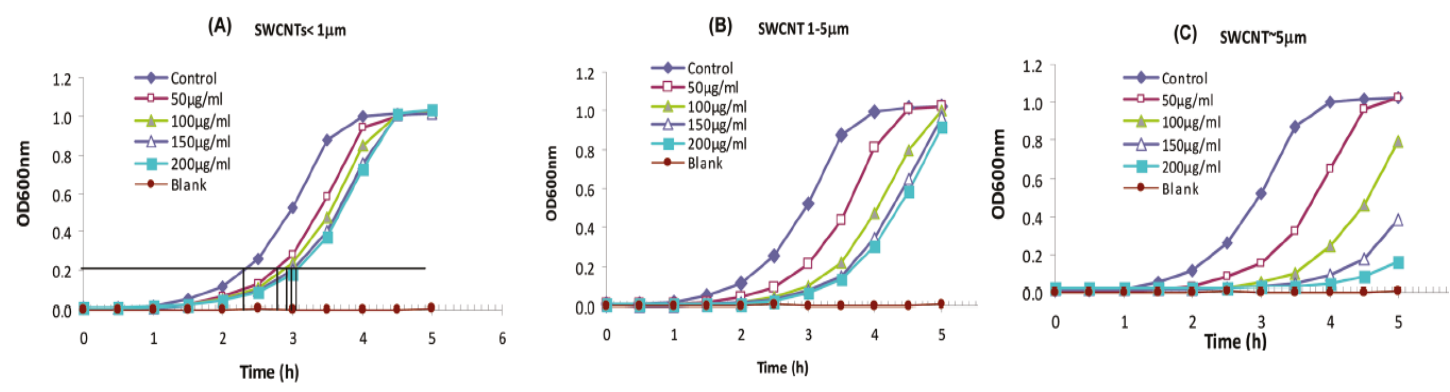

Figure 6. (A-C) Optical density (OD) growth curves measurement of Salmonella cells when $180 \mu \mathrm{L}$ of $\sim 8.0 \times 10^{7} \mathrm{cfu} / \mathrm{mL}$ cells was treated at the following conditions and grew in $5 \mathrm{~mL} \mathrm{BHI}$ at $37^{\circ} \mathrm{C}$ : (A) single-walled CNT (SWCNT) of $<1 \mu \mathrm{m}$ long, (B) 1-5 $\mu \mathrm{m}$ long, and (C) $5 \mu \mathrm{m}$ long, at various concentrations of blank, 50, 100, 150, and $200 \mu \mathrm{g} / \mathrm{mL}$ [62] (modified and cited with permission from ACS Chemical Society).

\subsection{Adsorption Activity CNT and Its Antimicrobial Application}

Usage of CNT for water purification has been on the increase as these filters can be cleaned repetitively for regaining full water filtering efficiency unlike other commercial water filters that only offers single usage policy [75-77]. Clearly, the benefits of possessing a large surface area gives an upper hand in water filtering systems as seen in SWCNT which retain a surface availability of approximately $407 \mathrm{~m}^{2} / \mathrm{g}$ that could aid in removing $3.18 \times 10^{12} \mathrm{CFU} / \mathrm{mL}$ of bacterial contaminants from raw drinking water supply $[76,78]$. Three major advantages have been claimed for utilization of CNT filters for water disinfection systems. First, the microbial adsorption capability of CNT is the highest recorded in the literature than the filters that are currently in use in the consumer's arena. Second, CNT filters have been demonstrated to have selective adsorptive behavior towards bacteria and lastly, the adsorption kinetics of CNT is very rapid signifying their use in biosensor applications [60]. Figure 6 shows that the High adsorption ratio of SWCNT are contributory to its highly fibrous nature of the nanomaterial that has been claimed to have an efficiency of adsorbing microbial spores of B. subtilis at 27-37 times greater than alumina-based adsorbents [62,79].

Selective behavior of CNT filters was first studied using mixed cultures of E. coli and S. aureus in the presence of SWCNT and it shows high selectivity towards certain species of bacteria. A 100 times greater adsorption values have been recorded for $S$. aureus compared to E. coli. The obtained results clearly confirm the adsorption mechanism dependent on size, morphology, and framework additive dispersion on CNT. The Gram-positive or Gram-negative bacteria differs their selectivity due to the morphology of the bacterial cell wall and outer membrane structure [22,53]. Lastly, good bacterial adsorption values of CNT have prompted the use of these nanomaterials to be applied in the field of bio sensing and detection techniques that involve bacterial culture are irrelevant. Kinetic rates of SWCNT are highly rapid where $95 \%$ of bacterial isolates that are present in the reaction mixture are captured and inactivated within 5 and 30 min especially in raw water [53,61]. Graphene oxide-based material has shown higher antibacterial activity toward P. aeruginosa and the antibacterial activity decrease in the following order such as reduced GO $>$ Graphite $>$ Graphite Oxide [78]. Hence, the mechanistic aspects of graphene oxide-based materials make challenges to predict the exact cell damage process in the surface of graphene layers. Two theoretical mechanism was already proposed, one is the interaction of 
graphene innovative insertion with cell membrane and another one could be destructive extraction of phospholipids from lipid membranes [77]. Kang et al. (2009) made systematic study of different varieties of carbon nanotube for both gram-positive and gram-negative bacteria (Figure 7 [61]). Figure 7 clearly shows that selectivity and activity of carbon nanotube is varied based on crystalline structure, band structure of carbon nanotubes, and morphology of different method prepared carbon-based nanomaterials [78-80].

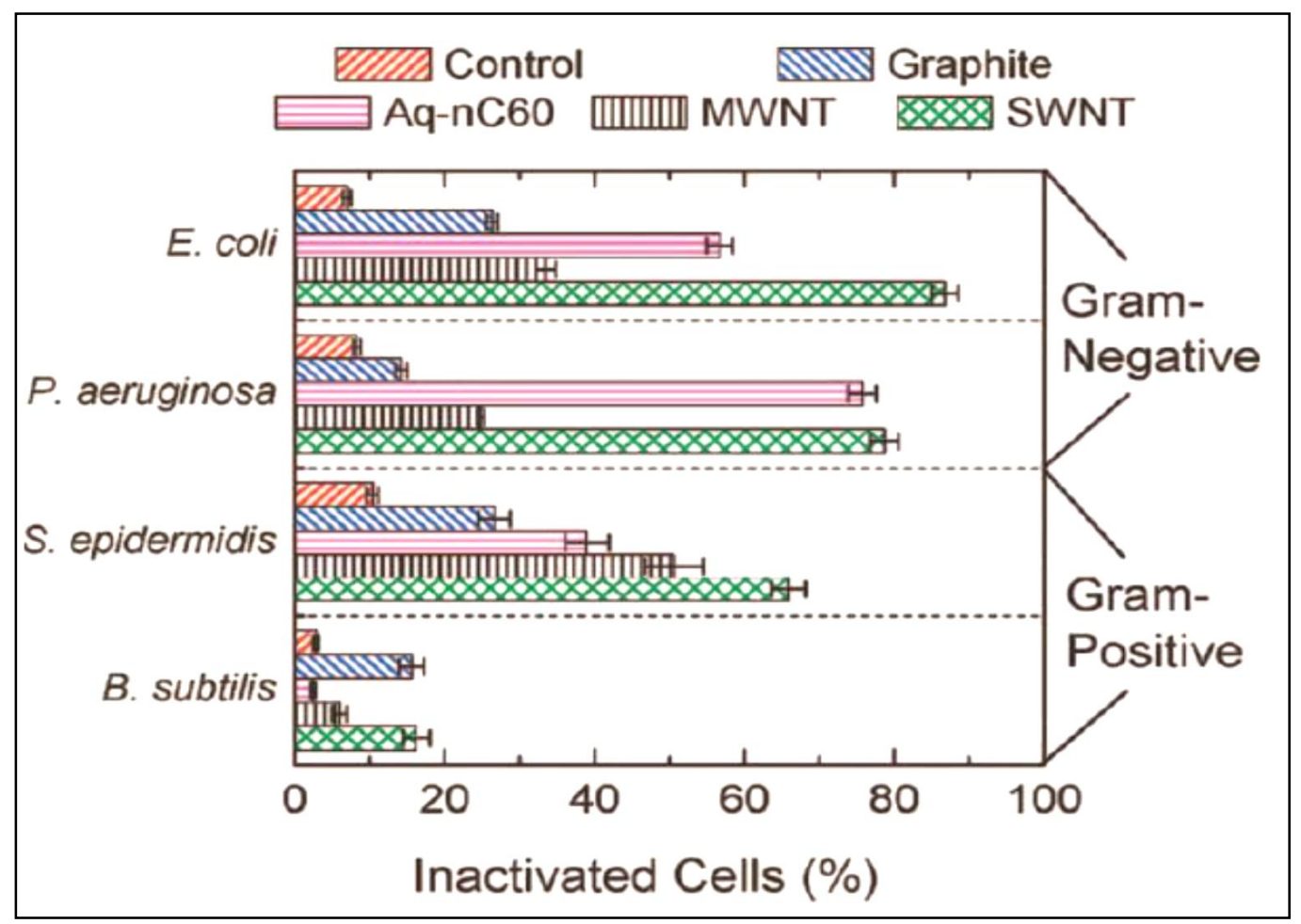

Figure 7. The schematic of fluorescence-based toxicity assays in the presence of different type of CNT against gram positive and negative bacteria. Reprinted with permission from referenced Kang et al. (2009). Acknowledged and cited [61,80] (Reproduced with permission and cited in references, ACS Chemical Socitey).

\subsection{Role of Electronic Structure of CNT in Antimicrobial Application}

The synthesized carbon nanotubes (CNT) often produce the metallic or semiconducting structures that are defined mainly through the carbon atom helical arrangement and the diameter of the nanotubes. Most often, one of three parts of the structures will display pseudo metallic characteristics, whereas the remaining two parts will comprise of nanotubes with semi-conducting properties [48,80]. The advanced method of preparation and purification process in the fabrication of individual SWCNT could be differentiated from other method prepared carbon nanomaterials in terms of its nanotube diameter, electronic structure and band gap CNT [81]. Therefore, the ability to separate SWCNT with varying electronic structures have made it possible to investigate the effects of this parameter in influencing the toxicity effects of CNT and improved antibacterial activity.

Increase in the fraction of metallic SWCNT in the solution mixture of nanotubes and bacteria have enhanced the oxidative stress experienced by the E. coli cells through loss of membrane integrity. SEM images clearly define the increase in the range of toxicity to the bacterial cells are associated with elevation in metallic properties of CNT fraction [48]. Carbon nanotube semiconducting property has changed from metallic and semi-metallic by functionalization of suitable quaternary ammonium salt addition and the specific selectivity towards the target was drastically changing with respect to fermi-energy level alteration in the band structure of carbon nanotubes [82]. The lone pairs present 
in nitrogen atom of diazonium salt react with carbon nanotubes and it extract electrons from the nanotube in the formation of covalent aryl bonds followed by transform its property from metallic to semi metallic nature and it results changes the biochemical-selectivity towards bacterial or any target species. Hence the addition of suitable additive internally or framework substitution of CNT could alter the metallic nature and its efficiency for specific application in the medical field.

\subsection{Antimicrobial Mechanisim Aspect of CNT Modified Materials for Water Treatment and Electrode Application}

A carbon filter made from traditional activated charcoal is still a potential as a water disinfectant in rural areas and adoption of low cost route prepared CNT could be employed into membranes to remove bacteria and viruses in water [83]. Brady et al. $(2008,2010)$ developed SWCNT filter with polymer membrane to inactivate bacteria and virus [84,85]. Similar work is carried out by Kang et al. (2009) on various bacterial species in water with respect to carbon nanotubes, which is already discussed earlier. Surface functionalization of CNT can increase the antimicrobial effect for water disinfectant. Nanocomposite-based on CNT with metal nanoparticles are promising candidates for antibacterial activity by synergistic mechanism between CNT and silver like nanoparticle deposition on the matrix of carbon network. Biogenic method prepared silver nanoparticle dispersion on reactive SWCNT could normalize the cytotoxicity of the SWCNT. No trace of viruses was found to flow through the filters after treatment with silver nanoparticle-based carbon nanotube in tea bag design filter usage in drinking water treatments. Silver nanocomposite towards E. coli and S. aureus improved significantly, with respect to silver loading [86,87]. The alternative low-cost metal oxide coating on CNT have also reported to treat the microorganism in water such as Zinc oxide, titanium dioxide, and ferric oxide. Recently, Ali et al. (2017) reported a class of novel multifunctional nanocomposites composed of MWCNT with iron oxide and silver nanoparticle coating provide the efficient damage for E. coli in drinking water [88]. Polymer coating on carbon nanotube is also an alternative filtration substrate for water treatments. In situ formation of carbon nanotube growth internally in the polymer membrane by novel design provide the improved antimicrobial activity for polymer-based carbon composite materials. In terms of electrode application of carbon nanotube with respect to microorganism, microbial fuel cell (MFC) is an ecofriendly method of wastewater treatment and self-powered electricity generation using microorganisms. The efficiency of MFC and chemical oxygen demand purely depends on physico chemical nature of CNT-based electrode materials. The biocompatibility of the CNT can be improved by surface oxidation. The 3D CNT anodes exhibit improved efficiency after deposition on biofilm and facilitates electron transfer process for improved performance [89]. Therefore, the fabrication of variety of CNT modified electrode and filtrate materials depend on low cost preparation strategy and play a crucial role in water treatment application and also in health care protective coating devices development in health care sector industry for future infection prevention aspects.

\section{Conclusions}

In summary, the present review article highlighted the significance of preparation strategy of functionalization and mechanistic aspects of carbon nanotube and graphene oxide-based carbon nanomaterials. Physicochemical characteristics of the carbon nanotube varieties are playing a definite role in determining the extent of the bacterial inactivation properties and therefore, future studies that involve investigations on the similar nature of this application should take into account the differences in the physical attributes of CNT and graphene oxide-based carbon nanomaterials. Diversity among the bacterial species could be taken into account and the above discussion highlighted the carbon-based nanomaterials application for antibacterial activity and water treatment/disinfectant process towards sustainable development. A deeper understanding of the growth and lifecycle of bacteria is required prior to the engineering of nanomaterial to combat bacterial and all possible viral infections, especially in the health care sector. 
Author Contributions: Conceptualization, J.R.R., G.P., P.A. and A.M.A.; methodology-M.G. and J.R.R.; writing-original draft preparation, J.R.R., A.M.A., P.A. and G.P.; writing-J.R.R., P.A. and G.P. review and editing, J.R.R., A.M.A., G.P. and P.A.; visualization, A.M.A.; supervision: J.R.R., Administration. J.R.R., G.P.; funding acquisition, J.R.R. All authors have read and agreed to the published version of the manuscript.

Funding: This research review work was funded by "Deputyship for Research and Innovation, "Ministry of Education" in Saudi Arabia through the project number IFKSURP-9, Kingdom of Saudi Arabia.

Acknowledgments: The authors extend their appreciation to the Deputyship for Research and Innovation, "Ministry of Education" in Saudi Arabia for funding this research work through the Project no. IFKSURP-9.

Conflicts of Interest: The authors declare no conflict of interest.

\section{References}

1. Han, Z.J.; Rider, A.E.; Fisher, C.; Van Der Laan, T.; Kumar, S.; Levchenko, I.; Ostrikov, K. Biological Application of Carbon Nanotubes and Graphene. In Carbon Nanotubes and Graphene, 2nd ed.; Elsevier: Amsterdam, The Netherlands, 2014; pp. 279-312.

2. Aqel, A.; El-Nour, K.M.A.; Ammar, R.A.; Al-Warthan, A. Carbon nanotubes, science and technology part (I) structure, synthesis and characterisation. Arab. J. Chem. 2012, 5, 1-23. [CrossRef]

3. Iijima, S. Helical microtubules of graphitic carbon. Nat. Cell Biol. 1991, 354, 56-58. [CrossRef]

4. Gao, J.; Yu, A.; Itkis, M.E.; Bekyarova, E.; Zhao, B.; Niyogi, S.; Haddon, R.C. Large-Scale Fabrication of Aligned Single-Walled Carbon Nanotube Array and Hierarchical Single-Walled Carbon Nanotube Assembly. J. Am. Chem. Soc. 2004, 126, 16698-16699. [CrossRef]

5. Chung, C.; Kim, Y.-K.; Shin, D.; Ryoo, S.-R.; Hong, B.H.; Min, D.-H. Biomedical Applications of Graphene and Graphene Oxide. Acc. Chem. Res. 2013, 46, 2211-2224. [CrossRef]

6. Novoselov, K.S.; Jiang, Z.; Zhang, Y.; Morozov, S.V.; Stormer, H.L.; Zeitler, U.; Maan, J.C.; Boebinger, G.S.; Kim, P.; Geim, A.K. Room-Temperature Quantum Hall Effect in Graphene. Science 2007, 315, 1379. [CrossRef]

7. Park, S.; Ruoff, R.S. Chemical methods for the production of graphenes. Nat. Nanotechnol. 2009, 4, 217-224. [CrossRef]

8. Slattery, A.D.; Blanch, A.J.; Quinton, J.S.; Gibson, C.T. Efficient attachment of carbon nanotubes to conventional and high-frequency AFM probes enhanced by electron beam processes. Nanotechnology 2013, 24, 235705. [CrossRef]

9. Slattery, A.D.; Shearer, C.J.; Shapter, J.G.; Gibson, C.T.; Gibson, C.T. Solution Based Methods for the Fabrication of Carbon Nanotube Modified Atomic Force Microscopy Probes. Nanomaterials 2017, 7, 346. [CrossRef]

10. Novoselov, K.S.; Geim, A.K.; Morozov, S.V.; Jiang, D.; Zhang, Y.; Dubonos, S.V.; Grigorieva, I.V.; Firsov, A.A. Electric Field Effect in Atomically Thin Carbon Films. Science 2004, 306, 666-669. [CrossRef]

11. Si, C.; Sun, Z.; Liu, F. Strain engineering of graphene: A review. Nanoscale 2016, 8, 3207-3217. [CrossRef]

12. Jain, K.K. Advances in use of functionalized carbon nanotubes for drug design and discovery. Expert Opin. Drug Discov. 2012, 7, 1029-1037. [CrossRef]

13. He, H.; Pham-Huy, L.A.; Dramou, P.; Xiao, D.; Zuo, P.; Pham-Huy, C. Carbon Nanotubes: Applications in Pharmacy and Medicine. BioMed Res. Int. 2013, 2013, 1-12. [CrossRef]

14. Amenta, V.; Aschberger, K. Carbon nanotubes: Potential medical applications and safety concerns. Wiley Interdiscip. Rev. Nanomed. Nanobiotechnol. 2014, 7, 371-386. [CrossRef]

15. Kang, S.; Pinault, M.; Pfefferle, L.D.; Elimelech, M. Single-Walled Carbon Nanotubes Exhibit Strong Antimicrobial Activity. Langmuir 2007, 23, 8670-8673. [CrossRef]

16. Kang, S.; Herzberg, M.; Rodrigues, D.F.; Elimelech, M. Antibacterial Effects of Carbon Nanotubes: Size Does Matter! Langmuir 2008, 24, 6409-6413. [CrossRef]

17. Kang, S.; Behrer, A.P.; Elimelech, M. Physicochemical Determinants of Multiwalled Carbon Nanotube Bacterial Cytotoxicity. Environ. Sci. Technol. 2008, 42, 7528-7534. [CrossRef]

18. Liu, S.; Wei, L.; Hao, L.; Fang, N.; Chang, M.W.; Xu, R.; Yang, Y.; Chen, Y. Sharper and Faster "Nano Darts" Kill More Bacteria: A Study of Antibacterial Activity of Individually Dispersed Pristine Single-Walled Carbon Nanotube. ACS Nano 2009, 3, 3891-3902. [CrossRef] [PubMed]

19. Pasquini, L.M.; Hashmi, S.M.; Sommer, T.J.; Elimelech, M.; Zimmerman, J.B. Impact of Surface Functionalization on Bacterial Cytotoxicity of Single-Walled Carbon Nanotubes. Environ. Sci. Technol. 2012, 46, 6297-6305. [CrossRef] 
20. Wang, K.; Shi, L.; Linthicum, W.; Man, K.; He, X.; Wen, Q.; Rojanasakul, L.W.; Rojanasakul, Y.; Yang, Y.; Wang, L. Substrate Stiffness-Dependent Carbon Nanotube-Induced Lung Fibrogenesis. Nano Lett. 2019, 19, 5443-5451. [CrossRef]

21. Smith, S.C.; Rodrigues, D.F. Carbon-based nanomaterials for removal of chemical and biological contaminants from water: A review of mechanisms and applications. Carbon 2015, 91, 122-143. [CrossRef]

22. Deokar, A.R.; Lin, L.-Y.; Chang, C.-C.; Ling, Y.-C. Single-walled carbon nanotube coated antibacterial paper: Preparation and mechanistic study. J. Mater. Chem. B 2013, 1, 2639-2646. [CrossRef] [PubMed]

23. Mocan, T.; Matea, C.T.; Pop, T.; Mosteanu, O.; Buzoianu, A.D.; Suciu, Ș.; Puia, C.; Zdrehus, C.; Iancu, C.; Mocan, L. Carbon nanotubes as anti-bacterial agents. Cell. Mol. Life Sci. 2017, 74, 3467-3479. [CrossRef] [PubMed]

24. Rajavel, K.; Gomathi, R.; Manian, S.; Kumar, R.T.R. In vitro bacterial cytotoxicity of CNT: Reactive oxygen species mediate cell damage edges over direct physical puncturing. Langmuir 2014, 30, 592-601. [CrossRef] [PubMed]

25. Maas, M. Carbon Nanomaterials as Antibacterial Colloids. Materials 2016, 9, 617. [CrossRef] [PubMed]

26. Yeh, Y.-T.; Gulino, K.; Zhang, Y.; Sabestien, A.; Chou, T.-W.; Zhou, B.; Lin, Z.; Albert, I.; Lu, H.; Swaminathan, V.; et al. A rapid and label-free platform for virus capture and identification from clinical samples. Proc. Natl. Acad. Sci. USA 2020, 117, 895-901. [CrossRef] [PubMed]

27. Tran, T.L.; Nguyen, T.T.; Chu, V.T.; Tran, Q.T.; Mai, A.T. Detection of influenza A virus using carbon nanotubes field effect transistor based DNA sensor. Phys. E Low Dimens. Syst. Nanostruct. 2017, 93, 83-86. [CrossRef]

28. Govindasamy, M.; Chen, S.-M.; Mani, V.; Devasenathipathy, R.; Umamaheswari, R.; Santhanaraj, K.J.; Sathiyan, A. Molybdenum disulfide nanosheets coated multiwalled carbon nanotubes composite for highly sensitive determination of chloramphenicol in food samples milk, honey and powdered milk. J. Colloid Interface Sci. 2017, 485, 129-136. [CrossRef]

29. Mani, V.V.; Mani, G.; Chen, S.M.; Karthik, R.; Huang, S.T. Determination of dopamine using a glassy carbon electrode modified with a graphene and carbon nanotube hybrid decorated with molybdenum disulfide flowers. Microchim Acta 2016, 183, 2267-2275. [CrossRef]

30. Svadlakova, T.; Hubatka, F.; Knotigova, P.T.; Kulich, P.; Masek, J.; Kotoucek, J.; Macak, J.; Motola, M.; Kalbac, M.; Kolackova, M.; et al. Proinflammatory Effect of Carbon-Based Nanomaterials: In Vitro Study on Stimulation of Inflammasome NLRP3 via Destabilisation of Lysosomes. Nanomaterials 2020, 10, 418. [CrossRef]

31. Moor, K.J.; Osuji, C.O.; Kim, J.-H. Dual-Functionality Fullerene and Silver Nanoparticle Antimicrobial Composites via Block Copolymer Templates. ACS Appl. Mater. Interfaces 2016, 8, 33583-33591. [CrossRef]

32. De Volder, M.; Tawfick, S.H.; Baughman, R.H.; Hart, A.J. Carbon Nanotubes: Present and Future Commercial Applications. Science 2013, 339, 535-539. [CrossRef] [PubMed]

33. Cha, C.; Shin, S.R.; Annabi, N.; Dokmeci, M.R.; Khademhosseini, A. Carbon-Based Nanomaterials: Multifunctional Materials for Biomedical Engineering. ACS Nano 2013, 7, 2891-2897. [CrossRef] [PubMed]

34. Ren, P.; Zheng, A.; Xiao, J.; Pan, X.; Bao, X. Exploring the ring current of carbon nanotubes by first-principles calculations. Chem. Sci. 2015, 6, 902-908. [CrossRef] [PubMed]

35. Kaicheng, Z.; Dougherty, C.A.; Zhu, K.; Hong, H. Theranostic applications of carbon nanomaterials in cancer: Focus on imaging and cargo delivery. J. Control. Release 2015, 210, 230-245.

36. Kharaziha, M.; Shin, S.R.; Nikkhah, M.; Topkaya, S.N.; Masoumi, N.; Annabi, N.; Dokmeci, M.R.; Khademhosseini, A. Tough and flexible CNT-polymeric hybrid scaffolds for engineering cardiac constructs. Biomaterials 2014, 35, 7346-7354. [CrossRef]

37. Costa, P.M.; Bourgognon, M.; Wang, J.T.-W.; Al-Jamal, K.T. Functionalised carbon nanotubes: From intracellular uptake and cell-related toxicity to systemic brain delivery. J. Control. Release 2016, 241, 200-219. [CrossRef]

38. Zou, X.; Zhang, L.; Wang, Z.; Luo, Y. Mechanisms of the Antimicrobial Activities of Graphene Materials. J. Am. Chem. Soc. 2016, 138, 2064-2077. [CrossRef]

39. Kronenberger, T.; Asse, L.R.; Wrenger, C.; Trossini, G.H.G.; Honorio, K.M.; Maltarollo, V.G. Studies of Staphylococcus aureus FabI inhibitors: Fragment-based approach based on holographic structure-activity relationship analyses. Futur. Med. Chem. 2017, 9, 135-151. [CrossRef]

40. Hu, W.; Peng, C.; Luo, W.; Lv, M.; Li, X.; Li, D.; Huang, Q.; Fan, C. Graphene-Based Antibacterial Paper. ACS Nano 2010, 4, 4317-4323. [CrossRef] 
41. Liu, C.; Shi, H.; Yang, H.; Yan, S.; Luan, S.; Li, Y.; Teng, M.; Khan, A.F.; Yin, J. Fabrication of antibacterial electrospun nanofibers with vancomycin-carbon nanotube via ultrasonication assistance. Mater. Des. 2017, 120, 128-134. [CrossRef]

42. Nepal, D.; Balasubramanian, S.; Simonian, A.L.; Davis, V.A. Strong Antimicrobial Coatings: Single-Walled Carbon Nanotubes Armored with Biopolymers. Nano Lett. 2008, 8, 1896-1901. [CrossRef] [PubMed]

43. Tiraferri, A.; Vecitis, C.D.; Elimelech, M. Covalent Binding of Single-Walled Carbon Nanotubes to Polyamide Membranes for Antimicrobial Surface Properties. ACS Appl. Mater. Interfaces 2011, 3, 2869-2877. [CrossRef] [PubMed]

44. Li, R.; Mansukhani, N.D.; Guiney, L.M.; Ji, Z.; Zhao, Y.; Chang, C.H.; French, C.T.; Miller, J.F.; Hersam, M.C.; Nel, A.E.; et al. Identification and Optimization of Carbon Radicals on Hydrated Graphene Oxide for Ubiquitous Antibacterial Coatings. ACS Nano 2016, 10, 10966-10980. [CrossRef] [PubMed]

45. Simmons, T.J.; Lee, S.H.; Park, T.J.; Hashim, D.P.; Ajayan, P.M.; Linhardt, R.J. Antiseptic single wall carbon nanotube bandages. Carbon 2009, 47, 1561-1564. [CrossRef]

46. Simmons, T.J.; Rivet, C.J.; Singh, G.; Beaudet, J.; Sterner, E.; Guzman, D.; Hashim, D.P.; Lee, S.-H.; Qian, G.; Lewis, K.M. Application of carbon nanotubes to wound healing biotechnology. In Nanomaterials for Biomedicine; ACS: Washington, DC, USA, 2012; pp. 155-174.

47. Tong, Z.; Bischoff, M.; Nies, L.F.; Myer, P.; Applegate, B.; Turco, R.F. Response of soil microorganisms to As-produced and functionalized single-wall carbon nanotubes (SWNTs). Environ. Sci. Technol. 2012, 46, 13471-13479. [CrossRef]

48. Vecitis, C.D.; Zodrow, K.R.; Kang, S.; Elimelech, M. Electronic-Structure-Dependent Bacterial Cytotoxicity of Single-Walled Carbon Nanotubes. ACS Nano 2010, 4, 5471-5479. [CrossRef]

49. Chen, H.; Wang, B.; Gao, D.; Guan, M.; Zheng, L.; Ouyang, H.; Chai, Z.; Zhao, Y.; Feng, W. Broad-Spectrum Antibacterial Activity of Carbon Nanotubes to Human Gut Bacteria. Small 2013, 9, 2735-2746. [CrossRef]

50. Zhao, C.; Deng, B.; Chen, G.; Lei, B.; Hua, H.; Peng, H.-L.; Yan, Z. Large-area chemical vapor deposition-grown monolayer graphene-wrapped silver nanowires for broad-spectrum and robust antimicrobial coating. Nano Res. 2016, 9, 963-973. [CrossRef]

51. Hossain, F.; Perales-Perez, O.J.; Hwang, S.; Román, F. Antimicrobial nanomaterials as water disinfectant: Applications, limitations and future perspectives. Sci. Total Environ. 2014, 466, 1047-1059. [CrossRef]

52. Arias, L.R.; Yang, L. Inactivation of Bacterial Pathogens by Carbon Nanotubes in Suspensions. Langmuir 2009, 25, 3003-3012. [CrossRef]

53. Deng, S.; Upadhyayula, V.K.; Smith, G.B.; Mitchell, M.C. Adsorption Equilibrium and Kinetics of Microorganisms on Single-Wall Carbon Nanotubes. IEEE Sens. J. 2008, 8, 954-962. [CrossRef]

54. Goy, R.C.; Morais, S.T.; Assis, O.B. Evaluation of the antimicrobial activity of chitosan and its quaternized derivative on E. coli and S. aureus growth. Rev. Bras. Farm. 2016, 26, 122-127. [CrossRef]

55. Kell, A.J.; Stewart, G.; Ryan, S.; Peytavi, R.; Boissinot, M.; Huletsky, A.; Bergeron, M.G.; Simard, B. Vancomycin-Modified Nanoparticles for Efficient Targeting and Preconcentration of Gram-Positive and Gram-Negative Bacteria. ACS Nano 2008, 2, 1777-1788. [CrossRef] [PubMed]

56. Imlay, J.A. The molecular mechanisms and physiological consequences of oxidative stress: Lessons from a model bacterium. Nat. Rev. Genet. 2013, 11, 443-454. [CrossRef]

57. Brinkman, C.L.; Schmidt-Malan, S.M.; Karau, M.J.; Greenwood-Quaintance, K.; Hassett, D.J.; Mandrekar, J.N.; Patel, R. Exposure of Bacterial Biofilms to Electrical Current Leads to Cell Death Mediated in Part by Reactive Oxygen Species. PLoS ONE 2016, 11, e0168595. [CrossRef] [PubMed]

58. Jeyaraj, M.; Rajesh, M.; Arun, R.; Mubarakali, D.; Sathishkumar, G.; Sivanandhan, G.; Kapil, G.; Manickavasagam, M.; Premkumar, K.; Thajuddin, N.; et al. Colloids and Surfaces B: Biointerfaces An investigation on the cytotoxicity and caspase-mediated apoptotic effect of biologically synthesized silver nanoparticles using Podophyllum hexandrum on human cervical carcinoma cells. Colloids Surf. B Biointerfaces 2013, 102, 708-717. [CrossRef]

59. Vatansever, F.; De Melo, W.C.; Avci, P.; Vecchio, D.; Sadasivam, M.; Gupta, A.; Chandran, R.; Karimi, M.; Parizotto, N.A.; Yin, R.; et al. Antimicrobial strategies centered around reactive oxygen species-bactericidal antibiotics, photodynamic therapy, and beyond. FEMS Microbiol. Rev. 2013, 37, 955-989. [CrossRef]

60. Upadhyayula, V.K.; Deng, S.; Mitchell, M.C.; Smith, G.B. Application of carbon nanotube technology for removal of contaminants in drinking water: A review. Sci. Total Environ. 2009, 408, 1-13. [CrossRef] 
61. Kang, S.; Mauter, M.S.; Elimelech, M. Microbial Cytotoxicity of Carbon-Based Nanomaterials: Implications for River Water and Wastewater Effluent. Environ. Sci. Technol. 2009, 43, 2648-2653. [CrossRef]

62. Yang, C.; Mamouni, J.; Tang, Y.; Yang, L. Antimicrobial Activity of Single-Walled Carbon Nanotubes: Length Effect. Langmuir 2010, 26, 16013-16019. [CrossRef]

63. Wick, P.; Manser, P.; Limbach, L.K.; Dettlaff-Weglikowska, U.; Krumeich, F.; Roth, S.; Stark, W.J.; Bruinink, A. The degree and kind of agglomeration affect carbon nanotube cytotoxicity. Toxicol. Lett. 2007, 168, 121-131. [CrossRef] [PubMed]

64. Calvaresi, M.; Zerbetto, F. Atomistic molecular dynamics simulations reveal insights into adsorption, packing, and fluxes of molecules with carbon nanotubes. J. Mater. Chem. A 2014, 2, 12123-12135. [CrossRef]

65. Prola, L.D.; Machado, F.M.; Bergmann, C.P.; De Souza, F.E.; Gally, C.R.; Lima, E.C.; Adebayo, M.A.; Dias, S.L.; Calvete, T. Adsorption of Direct Blue 53 dye from aqueous solutions by multi-walled carbon nanotubes and activated carbon. J. Environ. Manag. 2013, 130, 166-175. [CrossRef] [PubMed]

66. Upadhyayula, V.K.K.; Ruparelia, J.P.; Agrawal, A. Use of Carbon Nanotubes in Water Treatment. Nanoscale Multifunct. Mater. 2011, 321-368. [CrossRef]

67. Wang, R.; Mikoryak, C.; Li, S.; Bushdiecker, D., 2nd; Musselman, I.H.; Pantano, P.; Draper, R.K. Cytotoxicity screening of single-walled carbon nanotubes: Detection and removal of cytotoxic contaminants from carboxylated carbon nanotubes. Mol. Pharm 2011, 8, 1351-1361. [CrossRef] [PubMed]

68. Mauter, M.S.; Elimelech, M. Environmental Applications of Carbon-Based Nanomaterials. Environ. Sci. Technol. 2008, 42, 5843-5859. [CrossRef]

69. Agnihotri, S.; Mota, J.P.; Rostam-Abadi, M.; Rood, M.J. Structural Characterization of Single-Walled Carbon Nanotube Bundles by Experiment and Molecular Simulation. Langmuir 2005, 21, 896-904. [CrossRef]

70. Zhang, X.; Feng, Y.; Tang, S.; Feng, W. Preparation of a graphene oxide-phthalocyanine hybrid through strong $\pi-\pi$ interactions. Carbon 2010, 48, 211-216. [CrossRef]

71. Rodrigues, D.F.; Elimelech, M. Toxic Effects of Single-Walled Carbon Nanotubes in the Development of E. coli Biofilm. Environ. Sci. Technol. 2010, 44, 4583-4589. [CrossRef]

72. Bai, Y.; Park, I.S.; Lee, S.-J.; Bae, T.-S.; Watari, F.; Uo, M.; Lee, M.-H. Aqueous dispersion of surfactantmodified multiwalled carbon nanotubes and their application as an antibacterial agent. Carbon 2011, 49, 3663-3671. [CrossRef]

73. Geckeler, K.E.; Premkumar, T. Carbon nanotubes: Are they dispersed or dissolved in liquids? Nanoscale Res. Lett. 2011, 6, 136. [CrossRef] [PubMed]

74. Xing, Y.; Li, L.; Chusuei, C.C.; Hull, R.V. Sonochemical Oxidation of Multiwalled Carbon Nanotubes. Langmuir 2005, 21, 4185-4190. [CrossRef]

75. Murugan, E.; Vimala, G. Effective functionalization of multiwalled carbon nanotube with amphiphilic poly(propyleneimine) dendrimer carrying silver nanoparticles for better dispersability and antimicrobial activity. J. Colloid Interface Sci. 2011, 357, 354-365. [CrossRef] [PubMed]

76. Zhu, J.; Wang, J.; Hou, J.; Zhang, Y.; Liu, J.; Van Der Bruggen, B. Graphene-based antimicrobial polymeric membranes: A review. J. Mater. Chem. A 2017, 5, 6776-6793. [CrossRef]

77. Zardini, H.Z.; Amiri, A.; Shanbedi, M.; Maghrebi, M.; Baniadam, M. Enhanced antibacterial activity of amino acids-functionalized multi walled carbon nanotubes by a simple method. Colloids Surf. B Biointerfaces 2012, 92, 196-202. [CrossRef]

78. Zhou, R.; Gao, H. Cytotoxicity of graphene: Recent advances and future perspective. Wiley Interdiscip. Rev. Nanomed. Nanobiotechnol. 2014, 6, 452-474. [CrossRef]

79. Karlsson, H.L.; Cronholm, P.; Gustafsson, J.; Gustafsson, J.; Möller, L. Copper Oxide Nanoparticles Are Highly Toxic: A Comparison between Metal Oxide Nanoparticles and Carbon Nanotubes. Chem. Res. Toxicol. 2008, 21, 1726-1732. [CrossRef]

80. Doody, M.A.; Wang, D.; Bais, H.P.; Jin, Y. Differential antimicrobial activity of silver nanoparticles to bacteria Bacillus subtilis and Escherichia coli, and toxicity to crop plant Zea mays and beneficial B. subtilis-inoculated Z. mays. J. Nanoparticle Res. 2016, 18, 1-19. [CrossRef]

81. Arnold, M.S.; Green, A.A.; Hulvat, J.F.; Stupp, S.I.; Hersam, M.C. Sorting carbon nanotubes by electronic structure using density differentiation. Nat. Nanotechnol. 2006, 1, 60-65. [CrossRef]

82. Strano, M.S.; Dyke, C.A.; Usrey, M.L.; Barone, P.W.; Allen, M.J.; Shan, H.; Kittrell, C.; Hauge, R.H.; Tour, J.M.; Smalley, R.E. Electronic Structure Control of Single-Walled Carbon Nanotube Functionalization. Science 2003, 301, 1519-1522. [CrossRef] 
83. Vecitis, C.D.; Schnoor, M.H.; Rahaman, S.; Schiffman, J.D.; Elimelech, M. Electrochemical Multiwalled Carbon Nanotube Filter for Viral and Bacterial Removal and Inactivation. Environ. Sci. Technol. 2011, 45, 3672-3679. [CrossRef] [PubMed]

84. Brady-Estevez, A.S.; Kang, S.; Elimelech, M. A singlewalled-carbon-nanotube filter for removal of viral and bacterial pathogens. Small 2008, 4, 481-484. [CrossRef] [PubMed]

85. Brady-Estévez, A.S.; Nguyen, T.H.; Gutierrez, L.; Elimelech, M. Impact of solution chemistry on viral removal by a single walled carbon nanotube filter. Water Res. 2010, 44, 3773-3780. [CrossRef] [PubMed]

86. Kim, J.P.; Kim, J.H.; Kim, J.; Lee, S.N.; Park, H.-O. A nanofilter composed of carbon nanotube-silver composites for virus removal and antibacterial activity improvement. J. Environ. Sci. 2016, 42, 275-283. [CrossRef] [PubMed]

87. Chang, Y.-N.; Gong, J.; Zeng, G.-M.; Ou, X.-M.; Song, B.; Guo, M.; Zhang, J.; Liu, H.-Y. Antimicrobial behavior comparison and antimicrobial mechanism of silver coated carbon nanocomposites. Process. Saf. Environ. Prot. 2016, 102, 596-605. [CrossRef]

88. Ali, Q.; Ahmed, W.; Lal, S.; Sen, T. Novel Multifunctional Carbon Nanotube Containing Silver and Iron Oxide Nanoparticles for Antimicrobial Applications in Water Treatment. Mater. Today Proc. 2017, 4, 57-64. [CrossRef]

89. Chen, Y.; Lv, Z.; Xu, J.; Peng, D.; Liu, Y.; Chen, J.; Sun, X.; Feng, C.; Wei, C. Stainless steel mesh coated with $\mathrm{MnO} /$ carbon nanotube and polymethylphenyl siloxane as low-cost and high-performance microbial fuel cell cathode materials. J. Power Sources 2012, 201, 136-141. [CrossRef]

Publisher's Note: MDPI stays neutral with regard to jurisdictional claims in published maps and institutional affiliations.

(C) 2020 by the authors. Licensee MDPI, Basel, Switzerland. This article is an open access article distributed under the terms and conditions of the Creative Commons Attribution (CC BY) license (http://creativecommons.org/licenses/by/4.0/). 